\title{
AT-TARBAWI
}

At-Tarbawi: Jurnal Pendidikan, Sosial dan Kebudayaan

Volume 6 Nomor 1 Tahun 2019

doi: 10.32505/tarbawi.v6i1.1028

\section{Pemahaman Warga Matematika terhadap Konteks Visi, Misi, Tujuan Program Studi Pendidikan Matematika}

\author{
Mazlan \\ IAIN Langsa \\ mazlan@iainlangsa.ac.id
}

\begin{abstract}
The purpose of this study is to explain the level of student understanding of the context of the vision, mission, and objectives of the Mathematics Education Study Program (PMA Study Program). This study uses a quantitative descriptive approach. The questionnaire used is an open and closed questionnaire, meaning the questionnaire contains questions with four (4) answer choices and is accompanied by an explanation of the choice of the answer. The research sample was set at 20\%, namely as many as 61 students from each semester. The results of the study show; (1) almost all students are 60 people (98.36\%) who understand the context of the vision of superior words, 13 people including very understanding (21.31\%) and able to interpret professional words, and 60 people are very understanding $(98.36 \%)$ and able to interpret the words Rahmatan Lil Alamin, (2) Students almost entirely understand the mission of the first PMA Study Program (98.36\%), and so on with the same percentage for the second, third, and fourth missions, (3) Level Mathematicians' understanding of the context of the Study Program's objectives is to understand only the first goal with the number of students 55 students (90.16\%), while the second, third, fourth, fifth and sixth goals are in the very understand category of 9 people (14.75\%). So, in general, it can be said that PMA Study Program students almost all understand the context of the new PMA vision, mission, and objectives of the Study Program.
\end{abstract}

Keywords: Level of Understanding, Vision, Mission, and Objectives, Mathematics Education

\begin{abstract}
Abstrak
Tujuan penelitian ini untuk menjelaskan tingkat pemahaman mahasiswa terhadap konteks visi, misi, dan tujuan Program Studi Pendidikan Matematika (Prodi PMA).Penelitian ini menggunakan pendekatan kuantitatif deskriptif.Kuesioner yang digunakan adalah kuesioner terbuka dan tertutup, artinya kuesioner berisi pertanyaan dengan empat (4) pilihan jawaban dan disertai penjelasan atas pemilihan jawaban tersebut.Sampel penelitian ditetapkan sebesar 20\% yaitu sebanyak 61 orang mahasiswa dari tiap semester. Hasil penelitian menunjukkan; (1) hampir seluruhnya mahasiswa yaitu 60 orang (98,36\%)sangat paham konteks visi tentang kata unggul, 13 orang termasuk sangat paham $(21,31 \%)$ dan mampu mengartikan kata profesional, dan 60 orang sangat paham (98,36\%) serta mampu mengartikan kata rahmatan lil'alamin, (2) Mahasiswa hampir seluruhnya sangat paham akan misi Prodi PMA yang pertama (98,36\%), dan seterusnya dengan persentase yang sama untuk misi kedua, ketiga, dan keempat, (3) Tingkat pemahaman warga matematika terhadap konteks tujuan ProdiPMA yaitu sangat paham hanya pada tujuan yang pertama dengan jumlah mahasisswa 55 orang (90,16\%), sedangkan pada tujuan yang kedua, ketiga, keempat, kelima, dan keenam, berada pada kategori sangat paham sebanyak 9 orang $(14,75 \%)$. Jadi secara umum dapat dikatakan bahwa mahasiswa Prodi PMA hampir seluruhnya paham akan konteks visi, misi, dan tujuan Prodi PMA yang baru.
\end{abstract}

Kata Kunci: Tingkat Pemahaman, Visi, Misi, dan Tujuan, Pendidikan Matematika 


\section{A. Pendahuluan}

Perguruan tinggi ataupun lembaga pendidikan didirikan dengan sebuah impian, atau target masa depan oleh pendirinya atau pelaksana di lembaga tersebut. Cita-cita atau nilai inti dari perguruan tinggi atau lembaga pendidikan tersebut dirumuskan bersama oleh pelaksana sehingga berbentuk suatu pernyataan yang dikristalkan dalam sebuat kalimat yang disebut Visi. Visi dapat memberikan aspirasi dan motivasi, selain sebagai panduan atau rambu-rambu dalam menyusun suatu program studi. Sehingga sudah pasti apabila program studi ingin sukses maka harus memiliki visi yang digunakan untuk mencapai kesuksesannya itu.Adapun misi merupakan suatu pernyataan tentang apa yang harus dikerjakan oleh organisasi atau lembaga dalam usaha mewujudkan visi tersebut. Misi suatu lembaga diartikan sebagai tujuan dan alasan mengapa lembaga itu dibuat. Misi juga akan memberikan arah sekaligus batasan-batasan proses pencapaian tujuan.

Proses penyusunan visi misi, dan tujuan serta kurikulum program studi tentunya melalui serangkaian prosedur. Visi, mis dan tujuan program studi disusun saling terkait dengan visi misi dan tujuan fakultas serta mengacu pada visi, misi, dan tujuan intitusi serta melibatkan stakeholder. Adapun proses penyusunan visi, misi, tujuan, dan sasaran program studi Pendidikan Matematika FTIK IAIN Langsa diawali dengan (1) mempertimbangkan sejarah awal pendirian prodi PMA, perkembangan kurikulum, kebutuhan pasar kerja, serta perkembangan ilmu pengetahuan, dan teknologi; (2) mempertimbangkan hasil akreditasi prodi PMA pada tahun sebelumnya yaitu tahun 2016; (3) perubahan kurikulum perguruan tinggi menjadi Kerangka Kurikulum Nasional Indonesia yang dikenal sebagai KKNI; (4) memperhatikan dan mempertimbangkan masukan dosen, senat fakultas dan institut serta masukan dari pengguna alumni dan stakeholder; sehingga kemudian dilakukan pengkajian ulang terhadap visi, misi, tujuan, dan sasaran prodi PMA. 
Penetapan visi, misi, dan tujuan prodi pendidikan matematika tentunya dilanjutkan dengan proses sosialisasi visi dan misi tersebut dengan berbagai upaya, baik sosialisasi secara internal maupun sosialisasi secara eksternal. Sosialisasi internal ditujukan kepada dosen, mahasiswa, dan tenaga kependidikan di lingkungan Prodi Pendidikan Matematika FTIK IAIN Langsa.Sementara sosialisasi eksternal dialamatkan kepada orangtua mahasiswa dan kepada pemangku kepentingan atau stakeholder. Sosialisasi visi, misi, dan tujuan prodi pendidikan matematika dilakukan secara manual dan online, baik lisan maupun tertulis dan melalui website lembaga.

Teks dipahami sebagai suatu satuan bahasa terlengkap yang bersifat abstrak atau bentuk bahasa formal yang berupa kosa kata dan kalimat.Teks Visi hanya dapat diwujudkan jika konteks visi yang selanjutnya diwujudkan oleh Misi mampu dipahami oleh warga matematika.Adapun konteks sendiri bermakna bagian dari suatu teks atau uraian kalimat yang dapat mendukung atau menambah kejelasan makna.Sehingga pemahaman bacaan dalam hal ini pemahaman terhadap teks Visi dan Misi ialah kemampuan mengolah teks Visi dan Misi serta memahami maksud dari teks Visi dan Misi. Seseorang disebut paham jika mampu berperilaku sesuai dengan apa yang dipahaminya. Dalam hal ini warga matematika disebut paham visi Prodi Pendidikan matematika jika mampu menerjemahkan makna kata-kata yang termaktub di dalam redaksi visi, misi, dan tujuan Prodi PMA.

Studi ini mengkaji tingkat pemahaman warga matematika (khususnya mahasiswa) terhadap cita-cita prodi yaitu Visi dan Misi Prodi Pendidikan Matematika FTIK IAIN Langsa. Studi ini juga dapat digunakan sebagai umpan balik (feed back) bagi Program Studi Pendidikan Matematika Fakultas Tarbiyah dan Ilmu Keguruan Institut Agama Islam Negeri (FTIK IAIN) Langsa untuk mengevaluasi pemahaman warga matematika itu sendiri terhadap konteks visi, misi, dan tujuan prodi PMA.

Pemahaman berasal dari kata paham yang artinya "mengerti benar". Dalam pengetian yang lebih luas pemahaman dapat diartikan dengan mengerti benar sehingga dapat mengkomunikasikan dan mengajarkan kepada orang lain (Zevika dan Yerizon, 2012). Menurut Sudaryono (2012) 
pemahaman adalah kemampuan seseorang untuk mengerti dan memahami sesuatu setelah sesuatu itu diketahui atau diingat, yang mencakup kemampuan untuk menangkap makna dari arti dan bahan yang telah dipelajari, yang dinyatakan dengan menguraikan isi pokok dari suatu bacaan, atau mengubah data yang disajikan dalam bentuk tertentu ke bentuk yang lain.

Jadi pemahaman dapat dipahami sebagai kemampuan seseorang dalam mengetahui suatu hal ditandai dengan kemampuannya menyampaikan kembali isi suatu subyek daro obyek pengamatannya. Atau dengan kata lain, peserta didik mampu menyatakan kembali baik dalam bahasa verbal maupun nonverbal bahkan secara simbolik tentang obyek yang telah diketahuinya. Seorang peserta didik dikatakan memiliki pemahaman yang komprehensif apabila ia memiliki kemampuan menyampaikan dengan cara yang berbeda dari cara yang diperolehnya, sebab ia harus menghindari kemampuan menghapal (mengingat) sebagai kemampuan terendah dalam kognisi manusia.

Pemahaman merupakan tolok ukur kompetensi yang dicapai peserta didik setelah melakukan dan atau selesainya pembelajaran. Pemahaman atau comprehension diartikan sebagai kemampuan dalam memahami sesuatu yang akan dipelajari. Kemampuan-kemampuan yang dimaksud adalah (1) translasi; (2) interpretasi; dan (3) ekstrapolasi (Devetak, 2009). Indikator pencapaian tingkat pemahaman tersebut dapat diuraikan sebagai berikut:

1) Translasi

Kemampuan translasi dibagi menjadi dua yakni (a) kemampuan menerjemahkan suatu masalah yang diberikan dengan kata-kata abstrak menjadi kata-kata yang konkret; dan (b) kemampuan menerjemahkan hubungan yang ada dalam bentuk simbol, tabel, diagram, grafik, persamaan matematis, dan rumus-rumus lain ke dalam bentuk verbal atau sebaliknya.

2) Interpretasi

Interpretasi adalah kemampuan untuk memahami bahan atau ide yang direkan, diubah, atau disusun dalam bentuk lain. 


\section{3) Ekstrapolasi}

Ekstrapolasi adalah kemampuan untuk meramalkan kecenderungan yang ada menurut data tertentu dengan mengutarakan konsekuensi dan implikasi yang sejalan dengan kondisi yang digambarkan.

Jadi dapat disimpulkan, pemahaman adalah kesanggupan seseorang untuk dapat mendefinisikan sesuatu dan menguasai hal tersebut dengan memahami maknanya. Pemahaman berkaitan dengan kemampuan yang mengharapkan seseorang memahami makna dari sesuatu.

\section{B. Metode}

Jenis penelitian ini termasuk penelitian kuantitatif dengan format deskriptif. Saifuddin (2013) menegaskan bahwa penelitian deskriptif adalah penelitian yang bertujuan untuk menggambarkan secara sistematik dan akurat fakta dan karakteristik mengenai populasi atau mengenai bidang tertentu. Purwanto (2006) menambahkan bahwa penelitian deskriptif adalah penelitian yang hanya melibatkan satu variabel pada satu kelompok, tanpa menghubungkan dengan variabel lain atau membandingkannya dengan kelompok lain. Penelitian dilakukan atas satu kelompok dalam hal satu variabel.

Pada penelitian kuantitatif dengan format deskriptif survei memiliki ciri-ciri (1) pemairan ditonjolkan di hampir semua pengungkapannya dan (2) karena populasinya yang luas menyebabkan penelitian ini tidak mampu mencapai ke dalam data seperti dalam studi kasus, akan tetapi memungkinkan peneliti untuk menggeneralisasi suatu gejala sosial atau variabel sosial tertentu dengan populasi yang lebih besar (Bungin, 2013). Arikunto (2009) menambahkan bahwa survei dapat dilakukan untuk sesuatu hal data yang sifatnya nyata (tangible) artinya dapat diamati secara langsung.

Teknik sampling yang digunakan dalam penelitian ini adalah menggunakan sampel sistematis. Rancangan ini dilaksanakan dengan mengambil unit populasi dari atas ke bawah secara sistematis.Ditetapkan pengambilan sampeladalah $20 \%$ dari jumlah total populasi, sehingga sampel yang digunakan adalah sebanyak 61 orang mahasiswa dari tiap 
semester.Penelitian dilaksanakan pada program studi pendidikan matematika FTIK IAIN Langsa.Penelitian dilaksanakan mulai bulan Mei Oktober 2018. Kuesioner yang digunakan adalah kuesioner terbuka dan tertutup, artinya kuesioner berisi pertanyaan dengan empat (4) pilihan jawaban dan disertai penjelasan atas pemilihan jawaban tersebut. Pengukuran tingkat pemahaman menggunakan pengkategorian menurut Sartika (2015) yaitu:

Tabel 1 Parameter PenafsiranNilai Persentase

\begin{tabular}{|c|c|c|}
\hline No & Persentase & $\begin{array}{c}\text { Kriteria Tingkat } \\
\text { Pemahaman }\end{array}$ \\
\hline 1 & $0 \%$ & Tidak satupun \\
\hline 2 & $1 \%-25 \%$ & Sebagian kecil \\
\hline 3 & $26 \%-49 \%$ & Hampir setengahnya \\
\hline 4 & $50 \%$ & Setengahnya \\
\hline 5 & $51 \%-75 \%$ & Sebagian besar \\
\hline 6 & $76 \%-99 \%$ & Hampir seluruhnya \\
\hline 7 & $100 \%$ & Seluruhnya \\
\hline
\end{tabular}

\section{Hasil dan Pembahasan}

Rekapitulasi data dari uraian analisis tingkat pemahaman mahasiswa terhadap konteks Visi Program Studi Pendidikan Matematika dapat dilihat pada tabel 2 di bawah ini

Tabel 2. Rekapitulasi Tingkat Pemahaman Mahasiswa Terhadap Visi

\begin{tabular}{|l|c|c|c|c|c|c|}
\hline \multicolumn{1}{|c|}{ Visi } & \multicolumn{2}{c|}{ I } & \multicolumn{2}{c|}{ II } & \multicolumn{2}{c|}{ III } \\
\hline \multicolumn{1}{|c|}{ Kategori } & SP & P & SP & P & SP & P \\
\hline Skor & 4 & 3 & 4 & 3 & 4 & 3 \\
\hline $\begin{array}{l}\text { JumlahMahasi } \\
\text { swa }\end{array}$ & 60 & 1 & 13 & 48 & 60 & 1 \\
\hline Jumlah nilai & 240 & 3 & 52 & 144 & 240 & 3 \\
\hline Persentase & $98,36 \%$ & $1,23 \%$ & $\begin{array}{c}21,31 \\
\%\end{array}$ & $\begin{array}{c}59,01 \\
\%\end{array}$ & $98,36 \%$ & $1,23 \%$ \\
\hline \multicolumn{1}{|c|}{ Kriteria } & $\begin{array}{c}\text { Hampir } \\
\text { Seluruhn } \\
\text { ya }\end{array}$ & $\begin{array}{c}\text { Sebagi } \\
\text { an } \\
\text { Kecil }\end{array}$ & $\begin{array}{c}\text { Sebagi } \\
\text { an } \\
\text { Kecil }\end{array}$ & $\begin{array}{c}\text { Sebagi } \\
\text { an } \\
\text { Besar }\end{array}$ & $\begin{array}{c}\text { Hampir } \\
\text { Seluruhny } \\
\text { a }\end{array}$ & $\begin{array}{c}\text { Sebagia } \\
\text { n Kecil }\end{array}$ \\
\hline
\end{tabular}


Untuk lebih jelasnya bisa dilihat pada gambar1. dibawah ini:

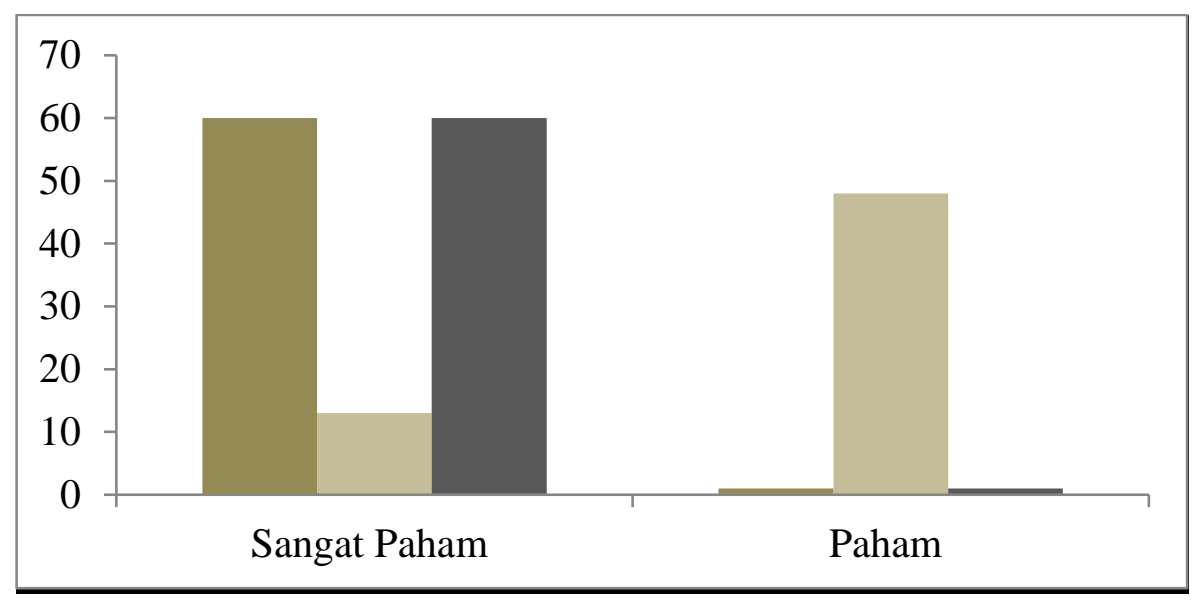

\section{Gambar 1. Rekapitulasi Perolehan Terhadap Visi PMA}

Tabel 2. di atas menunjukkan bahwa tingkat pemahaman mahasiswa terhadap visi program studi pendidikan matematika yaitu hampir seluruhnya mahasiswa sangat paham akan aspek visi PMA yang pertama dan ketiga, mahasiswa bisa menjelaskan dengan baik dan benar secara jelas dan sistematis, sedangkan pada aspek visi yang kedua mahasiswa lebih banyak yang hanya bisa memahaminya tanpa bisa menjelaskan secara sistematis. Rekapitulasi data dari uraian analisis tingkat pemahaman mahasiswa terhadap konteksMisi Program Studi Pendidikan Matematika dapat dilihat pada tabel 3 di bawah ini:

Tabel 3. Rekapitulasi Tingkat Pemahaman Mahasiswa Terhadap Misi

\begin{tabular}{|l|c|c|c|c|c|c|c|c|}
\hline \multicolumn{1}{|c|}{ Misi } & \multicolumn{2}{|c|}{ I } & \multicolumn{2}{c|}{ II } & \multicolumn{2}{c|}{ III } & \multicolumn{2}{c|}{ IV } \\
\hline Kategori & SP & $\mathbf{P}$ & SP & P & SP & P & SP & P \\
\hline Skor & 4 & 3 & 4 & 3 & 4 & 3 & 4 & 3 \\
\hline $\begin{array}{l}\text { Jumlah } \\
\text { mahasisw } \\
\text { a }\end{array}$ & 60 & 1 & 60 & 1 & 60 & 1 & 60 & 1 \\
\hline Jumlah & 240 & 3 & 240 & 3 & 240 & 3 & 240 & 3 \\
\hline$\%$ & $98,36 \%$ & $1,23 \%$ & $98,36 \%$ & $1,23 \%$ & $98,36 \%$ & $1,23 \%$ & $98,36 \%$ & $1,23 \%$ \\
\hline Kriteria & $\begin{array}{c}\text { Hampir } \\
\text { Seluruh } \\
\text { nya }\end{array}$ & $\begin{array}{c}\text { Sebagia } \\
\text { n Kecil }\end{array}$ & $\begin{array}{c}\text { Hampir } \\
\text { Seluruhn } \\
\text { ya }\end{array}$ & $\begin{array}{c}\text { Sebagian } \\
\text { Kecil }\end{array}$ & $\begin{array}{c}\text { Hampir } \\
\text { Seluruhny } \\
\text { a }\end{array}$ & $\begin{array}{c}\text { Sebagian } \\
\text { Kecil }\end{array}$ & $\begin{array}{c}\text { Hampir } \\
\text { Seluruhn } \\
\text { ya }\end{array}$ & $\begin{array}{c}\text { Sebagia } \\
\text { n Kecil }\end{array}$ \\
\hline
\end{tabular}


Untuk lebih jelasnya bisa dilihat pada gambar 2. dibawah ini:

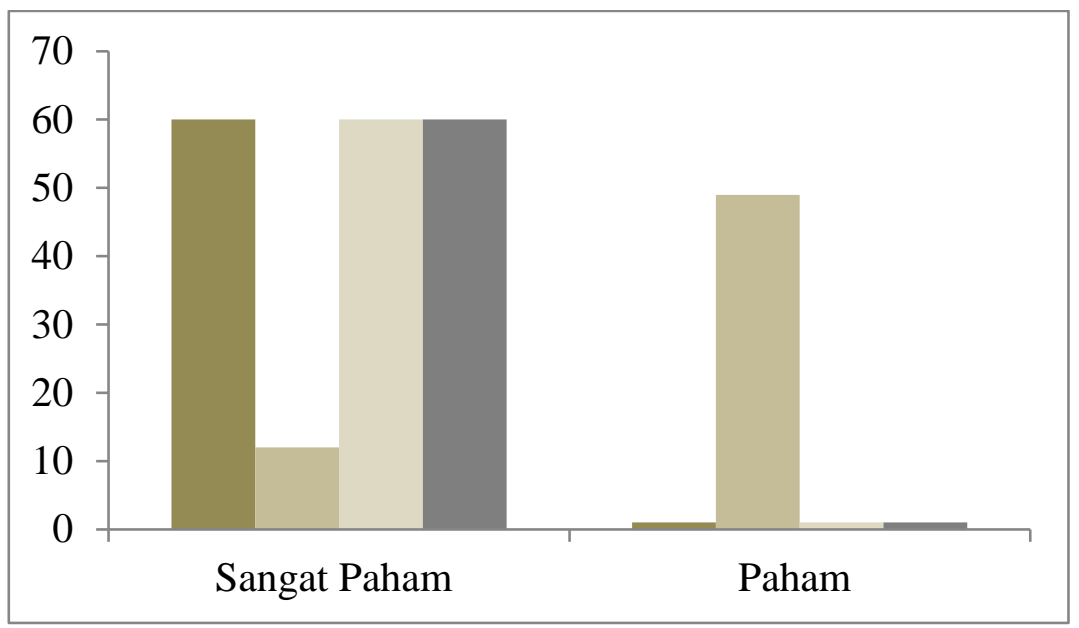

Gambar 2. Rekapitulasi Pemahaman Mahasiswa Terhadap Misi

Tabel 3. di atas menunjukkan bahwa tingkat pemahaman mahasiswa terhadap misi program studi pendidikan matematika yaitu hampir seluruhnya mahasiswa sangat paham akan misi PMA yang pertama, ketiga dan keempat, dimana mahasiswa bisa menjelaskan dengan baik dan benar secara jelas dan sistematis misi dari PMA, sedangkan pada misi yang kedua mahasiswa lebih banyak yang hanya bisa memahaminya tanpa bisa menjelaskan secara sistematis. Rekapitulasi data dari analisis tingkat pemahaman mahasiswa terhadap kontekstujuan Program Studi Pendidikan Matematika dapat dilihat pada tabel 4 di bawah ini:

Tabel 4. Rekapitulasi Tingkat Pemahaman Mahasiswa Terhadap Tujuan

\begin{tabular}{|l|c|c|c|c|c|c|}
\hline \multicolumn{1}{|c|}{ Tujuan } & \multicolumn{2}{|c|}{ I } & \multicolumn{2}{c|}{ II } & \multicolumn{2}{c|}{ III } \\
\hline \multicolumn{1}{|c|}{ Kategori } & SP & P & SP & P & SP & P \\
\hline Skor & 4 & 3 & 4 & 3 & 4 & 3 \\
\hline $\begin{array}{l}\text { Jumlah } \\
\text { mahasiswa }\end{array}$ & 55 & 6 & 9 & 52 & 9 & 52 \\
\hline Jumlah & 220 & 18 & 36 & 156 & 36 & 156 \\
\hline$\%$ & $90,16 \%$ & $7,37 \%$ & $14,75 \%$ & $63,93 \%$ & $14,75 \%$ & $63,93 \%$ \\
\hline \multicolumn{1}{|c|}{ Kriteria } & $\begin{array}{c}\text { Hampir } \\
\text { Seluruhnya }\end{array}$ & $\begin{array}{c}\text { Sebagian } \\
\text { Kecil }\end{array}$ & $\begin{array}{c}\text { Sebagian } \\
\text { Kecil }\end{array}$ & $\begin{array}{c}\text { Sebagian } \\
\text { Besar }\end{array}$ & $\begin{array}{c}\text { Sebagian } \\
\text { Kecil }\end{array}$ & $\begin{array}{c}\text { Sebagian } \\
\text { Besar }\end{array}$ \\
\hline
\end{tabular}


Tabel 5. Rekapitulasi Tingkat Pemahaman Mahasiswa Terhadap Tujuan

\begin{tabular}{|l|c|c|c|c|c|c|}
\hline \multicolumn{1}{|c|}{ Tujuan } & \multicolumn{2}{|c|}{ IV } & \multicolumn{2}{c|}{ V } & \multicolumn{2}{c|}{ VI } \\
\hline \multicolumn{1}{|c|}{ Kategori } & SP & P & SP & P & SP & P \\
\hline Skor & 4 & 3 & 4 & 3 & 4 & 3 \\
\hline $\begin{array}{l}\text { Jumlah } \\
\text { mahasiswa }\end{array}$ & 9 & 52 & 9 & 52 & 9 & 52 \\
\hline Jumlah & 36 & 156 & 36 & 156 & 36 & 156 \\
\hline$\%$ & $14,75 \%$ & $63,93 \%$ & $14,75 \%$ & $63,93 \%$ & $14,75 \%$ & $63,93 \%$ \\
\hline \multicolumn{1}{|c|}{ Kriteria } & $\begin{array}{c}\text { Sebagian } \\
\text { Kecil }\end{array}$ & $\begin{array}{c}\text { Sebagian } \\
\text { besar }\end{array}$ & $\begin{array}{c}\text { Sebagian } \\
\text { Kecil }\end{array}$ & $\begin{array}{c}\text { Sebagian } \\
\text { besar }\end{array}$ & $\begin{array}{c}\text { Sebagian } \\
\text { Kecil }\end{array}$ & $\begin{array}{c}\text { Sebagian } \\
\text { besar }\end{array}$ \\
\hline
\end{tabular}

Untuk lebih jelasnya bisa dilihat pada gambar 3. dibawah ini:

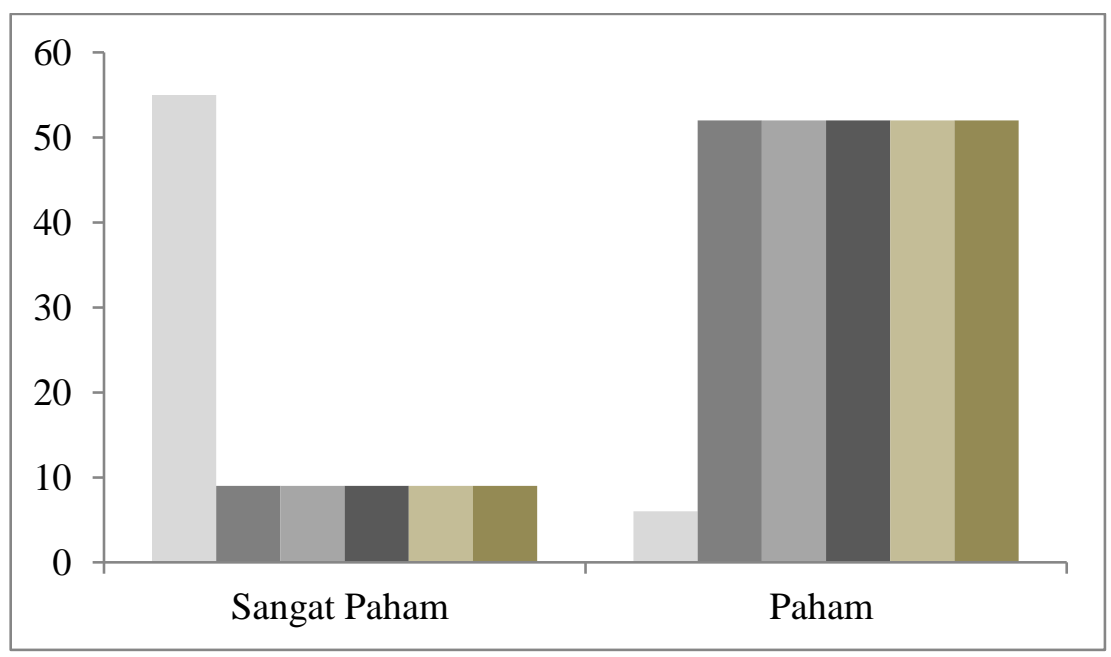

Gambar 3.Rekapitulasi Pemahaman Mahasiswa Terhadap Tujuan

Tabel 4 dan 5 di atas menunjukkan bahwa tingkat pemahaman mahasiswa terhadap tujuan program studi pendidikan matematika pada katagori sangat paham hanya pada tujuan yang pertama, dimana mahasiswanya hampir seluruhnya sangat paham akan tujuan dari PMA, mereka bisa menjelaskan dengan baik benar, dan sistematis tujuan dari PMA, sedangkan pada tujuan yang kedua sampai keenam mahasiswanya sebagian besar hanya bisa memahaminya tanpa bisa menjelaskan secara sistematis. 


\section{KESIMPULAN}

Adapun kesimpulan dari penelitian ini adalah

1. Tingkat pemahaman warga matematika terhadap konteks visi program studi pendidikan matematika FTIK IAIN Langsa yaitu:

a) Hampir seluruhnya mahasiswa sangat paham akan aspek visi PMA yang pertama dengan jumlah mahasiswa 60 orang termasuk sangat paham $(98,36 \%)$, karena mampu mengartikan kata unggul dengan baik dan benar;

b) Kemudian aspek visi PMA yang kedua dengan jumlah mahasiswa 13 orangtermasuk sangat paham (21,31\%) dan mampu mengartikan kata profesional dengan baik dan benar;

c) Dan aspek visi PMA yang ketiga dengan jumlah mahasiswa 60 orang termasuk sangat paham (98,36\%) serta mampu mengartikan kata rahmatan lil'alamin dengan baik dan benar.

2. Tingkat pemahaman warga matematika terhadap konteks misi program studi pendidikan matematika FTIK IAIN Langsa yaitu hampir seluruhnya mahasiswa sangat paham akan misi PMA yang pertama dengan jumlah mahasiswa 60 orang (98,36\%), pemahaman akan misi prodi dapat diuraikan sebagai berikut:

a) Pada misi pertama, tingkat pemahaman mahasiswa termasuk dalam kriteria hampir seluruhnya sangat paham.

b) Kemudian pada misi yang kedua dengan jumlah mahasiswa 12 orang termasuk sangat paham $(19,67 \%)$.

c) Pada misi yang ketiga dengan jumlah mahasiswa 60 orang termasuk sangat paham $(98,36 \%)$.

d) Selanjutnya pada misi yang keempat dengan jumlah mahasiswa 60 orang termasuk sangat paham $(98,36 \%)$.

3. Tingkat pemahaman warga matematika terhadap konteks tujuan program studi pendidikan matematika FTIK IAIN Langsa yaitu:

a) Pada katagori sangat paham hanya pada tujuan yang pertama dengan jumlah mahasisswa 55 orang (90,16\%), mereka bisa menjelaskan dengan baik benar, dan sistematis tujuan dari PMA. 
b) Sedangkan pada tujuan yang kedua dengan jumlah mahasiswa yang sangat paham 9 orang (14,75\%), mereka bisa menjelaskan dengan baik tujuan dari PMA.

c) Kemudian pada tujuan yang ketiga dengan jumlah mahasiswa yang sangat paham 9 orang (14,75\%), mereka bisa menjelaskan dengan baik tujuan dari PMA.

d) Pada tujuan yang keempat dengan jumlah mahasisswa yang sangat paham 9 orang $(14,75 \%)$, mereka bisa menjelaskan dengan baik tujuan dari PMA.

e) Selanjutnya pada tujuan yang kelima dengan jumlah mahasisswa yang sangat paham 9 orang $(14,75 \%)$, mereka bisa menjelaskan dengan baik tujuan dari PMA.

f) Pada tujuan yang kelima dengan jumlah mahasisswa yang sangat paham 9 orang $(14,75 \%)$, mereka bisa menjelaskan dengan baik tujuan dari PMA.

g) Terakhir pada tujuan yang keenam dengan jumlah mahasisswa yang sangat paham 9 orang $(14,75 \%)$, mereka bisa menjelaskan dengan baik tujuan dari PMA.

\section{E. Saran}

Disaran pada peneliti lain untuk dapat mengembangkan penelitian ini lebih detail lagi dan bisa menjadi rujukan bagi prodi pendidikan matematika.

\section{UCAPAN TERIMA KASIH}

Penulis mengucapkan terima kasih kepada seluruh dosen Pendidikan Matematika dan juga dosen Tarbiyah serta seluruh mahasiswa PMA atas dukungannya baik secara material maupun secara moril. 


\section{DAFTAR PUSTAKA}

Arikunto, S. 2006. Dasar-Dasar Evaluasi Pendidikan.: Bumi Aksara. Jakarta.

Borang Akreditasi Prodi.Pendidikan Matematika IAIN Zawiyah Cotkala langsa 2016.

Bungin, B. 2013.Metodedologi Penelitian Sosial dan Ekonomi. Prenadamedia Group. Jakarta.

Hikman, R. 1990. Mind Manager, Soul of Leader. Wiley and Son. New York.

Kanafi, Imam, dkk. 2013. Persepsi dan Transformasi Visi dan Misi Pada Civitas Akademika STAIN Pekalongan.

Kuncoro. 2006. Strategi: Bagaimana Meraih Keunggulan Kompetitif. Erlangga. Jakarta.

Notohadiprawiro. 2006. Masyarakat Perguruan Tinggi. Universitas Gajah Mada. Yogyakarta.

Novita Mariana, dkk. 2015. Tracer Studi Mahasiswa Program Studi Sistem Informasi Universitas Stikubank Semarang (Jurnal Dinamika Informatika.Vol. 7 No, 2, Oktober 2015, ISSN 2085 - 3343).

Purwanto. 2008. Metodologi Penelitian Kuantitatif. Pustaka Pelajar. Yogyakarta.

Sagala, S. 2013. Konsep Dan Makna Pembelajaran. Alfabeta. Bandung.

Saifuddin, A. 2013.Metode Penelitian. Pustaka Pelajar. Yogyakarta.

Sunardi, D dan Sudarwati, W. 2014.Pengukuran TIngkat Pemahaman Civitas Akademika Terhadap Visi Misi Jurusan Teknik Industri.(online) http://download.portalgaruda.org/article.php?article=298258\&val=7 261\&title=PENGUKURAN\%20TINGKAT\%20PEMAHAMAN\%20CIVITA S\%20AKADEMIKA\%20TERHADAP\%20VISI\%20MISI\%20JURUSAN\%2 0TEKNIK\%20INDUSTRI.

Sunaryo, W. K. 2012.Taksonomi Kognitif. PT Remaja Rosda Karya. Bandung.

Susanto, A. 2013.Teori Belajar dan Pembelajaran di Sekolah Dasar. PT Fajar Interpratama Mandiri. . Jakarta.

UII, 2009, Dokumen Blue Print Manajemen Alumni, Universitas islam Indonesia, Yogyakarta.

Usman, H. 2011. Manajemen Teori, Praktik, dan Riset Pendidikan. Bumi Aksara. Jakarta. 
Tulasi, D. 2010. Merunut Pemahaman Taksonomi Bloom: Suatu Kontemplasi Filosofis. Humaniora Volume 1 Nomor 2 Oktober 2010: 359-371.

Wibisono, D. 2006.Manajemen Kinerja, Konsep, Desain, dan Teknik Perusahaan. Erlangga. Jakarta.

Zevika dan Yerizon. 2012. Meningkatkan Kemampuan Pemahaman Konsep Siswa Kelas VIII SMP Negeri 2 Padang Panjang Melalui Pembelajaran Kooperatif Tipe Think Pair Share Disertai Peta Pikiran. Jurnal Pendidikan Matematika, Volume 1 Nomor 1: 45. 
